\title{
内航一般貨物船におけるトリップ連鎖パターンの 形成メカニズムに関する研究
}

\author{
小谷通泰 $^{1}$ ・ 岡山正人 ${ }^{2}$ \\ 1)正会員 工博 神戸商船大学 輸送システム工学講座 助教授（テ658 神戸市東灘区深江南町 5-1-1）

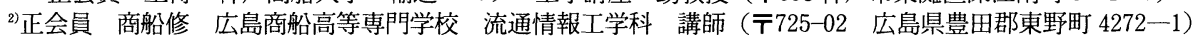

\begin{abstract}
本研究は, 内航船舶を対象とした起終点調査の結果をもとに, 主要船種である一般貨物船のトリップ連鎖パ ターンの形成メカニズムを明らかにしょうとしたものである.この結果, ベース港を中心とした $5 つ$ 連鎖パ ターンを抽出した。 また, 各船舶は連鎖パターン内の第 1 トリップを中心に運航されており, 各連鎖パターン が, 第 1 トリップが終了しベース港へ帰港する際に，輸送の効率性とりわけ空船回航を避けるように帰り荷貨物 を選択することで形成されていることを示した。ささらに，連鎖パターンの構成此率が第 1 トリップ長により異な ることを示すとともにその理由あ明かにした。
\end{abstract}

Key Words : trip chaining, coastal shipping, cargo transport

\section{1. はじめに}

船舶などによる貨物輸送では，貨物を集配送するため に複数の地点を巡回するトリップや，空荷での回送のた めのトリップが生じるため, 貨物の流動とそれを運ぶ輸 送機関の OD とは必ずしも一致しない。このため, 船舶 交通量を貨物流動量から推計するためには, 船舶が貨物 を輸送する際によ゙のように配船・運航されているかを明 らかにしていく必要がある.

ところでこうした貨物の OD とそれを輸送する船舶の $\mathrm{OD}$ とのくい違いを生じさせる貨物の集配活動や空船回 航トリップなどは，それぞれのトリップを独立したもの としてではなく，前後に行われるトリップとの関連の中 で分析することが有効となろう。なぜなら，貨物の集配 活動はそれを行っている数トリップすべてに着目した分 析を行うことではじめて発見できるであろうし，空船卜 リップはそれを含む一連のトリップの中で輸送の効率性 といった要因を考慮して行われているものと考えられ る.

このような観点から本研究では, 内航船舶を対象に行 われた起終点調査の結果をむとに, 内航船舶の主要船種 である一般貨物船について， ある一定の期間内における 船舶の交通軌跡をトリップの連鎖すなわちトリップチェ インとみなし，その連鎖パターンの形成メカニズムを明 らかにすることを目的としたものである.

\section{2. 従来の研究亡本研究の特徵}

従来から，交通行動を分析するためにトリップチェイ ンによるアプローチが適用されているが, 本研究と関連 が深い業務交通については以下のような研究がある. 近 藤らは貨物車による業務交通のストップ数分布およびサ イクル数分布を推計する手法を提案している 佐木らはトリップ連鎖パターンを考慮した業務交通の発 生集中量の分析を試みている22. 最近のトリップチェイ ンアプローチに打ける研究では，時間的および空間的制 約が交通行動に大きく影響を与えることに着目したもの が数多く見られるが3 , 加藤らはそうした考えを業務交 通に適用し，帰社率とサイクル終了率が時刻に依存する こと, ストップ数生起確率とサイクル発生確率が幾何分 布に従うとすることなどにより, 時間帯別の業務交通量 を推計するモデルを提案している4 ${ }^{4}$.一方,この研究に見ら れるように，ストップ数生起確率が幾何分布に従うとす るトリップチェイン分析はいくつか存在するが，著者ら 屯一般貨物船について, 訪問港数が幾何分布に従うとし て, 第 1 トリップ長の距離帯別に訪問港数が等しい連鎖 パターンの生成確率を推計するモデルを提案している5 .

船舶交通の分析にトリップチェインの考え方を適用し たものは著者らの研究以外には見られないが，トリップ チェイン的アプローチにより船舶交通を分析していくに はいくつかの問題点がある. まず 1 つは, ベース港の決 定方法である. 船舶の場合はパーソントリップなどと異 なり，自宅やオフィスというような明確なべースが存在 しない，そのため，何らかの方法でべース港となる港を 
決定する必要が生じる.今 1 つは，連鎖パターンの類型 化の方法である. 船舶は他の業務トリップやパーソント リップのように 1 日という時間制約下で運航されていな いため, トリップチェインの終点が不明であること, さ らに先にも述べたように，その運航形態を明らかにする ためには, 貨物輸送の形態む同時に把握する必要がある ことなど，こうしたことを考慮にいれて連鎖パターンを 類型化する必要がある.

著者らはすでに, 様々な種類の内航船舶を対象にし て, 寄港地のうちで貨物の積み込み量の最む多い港をそ の船舶にとってのベースとすることを提案し, その有効 性を確かめている. また, 連鎖パターンの類型化におい ても, ベース港を出発して再びベース港に戻ってくるま での一連のトリップの連鎖について，その連鎖内の訪問 港の数に着目することで, 船舶のトリップ連鎖パターン の類型化を試みてきた6).

本研究では, こうした成果を踏まえて, 内航船舶のう ち一般貨物船を対象として, まずベース港を中心とした トリップ連鎖パターンを, 従来の訪問港の数に加えて, 空船回航の現れ方や貨物の配送の有無などに着目するこ とで抽出する. そして，各連鎖パターンの第 1 トリップ がその連鎖パターンを決定する主な要因であることを明 らかにする．またさらに，第 1 トリップと第 1 トリップ 以外の貨物を輸送しているトリップとの間で積載貨物の 種類数や積載率を比較することにより，第 1 トリップ以 外の貨物を輸送しているトリップが, ベース港に戻って くる際に行われる帰り荷輸送であることを明らかにす る.

次に，第 1 トリップ以外で輸送される貨物がどのよう な要因に基づいて選択されるかを示し，そうした要因と 連鎖パターンの形成との関連性について考察する.

最後に, こうして得られた分析結果をもとにして, 連 鎖パターンの形成メカニズムについて考察する.

先に述べたように, 最近のトリップチェインアプロー チによる貨物車などの業務交通の研究では, 時間制約に 着目することで, その運行を分析したり, 交通需要量を 求めようとするむのが多い. しかし, 貨物需要との関係 にまで遡って輸送機関の運行パターンを分析しようとす るものは限られており, 国内では西井らによる貨物車の 運行を連鎖パターン内の貨物の揚げ積みに着目して分析 しようとしたもの林見られる程度である.しかも，これ らは連鎖パターン内における貨物の揚げ積みの実態を分 析するにとよ゙まっており，こうした貨物の揚げ積みが， 連鎖パターン形成によ゙のように関わっているのかについ ては言及していない，本研究では, 船舶が貨物輸送をい かに行っているかを明らかにしながら，この結果をもと に船舶のトリップ連鎖パターンの形成メカニズムを考察 しようとするところに特徴がある.

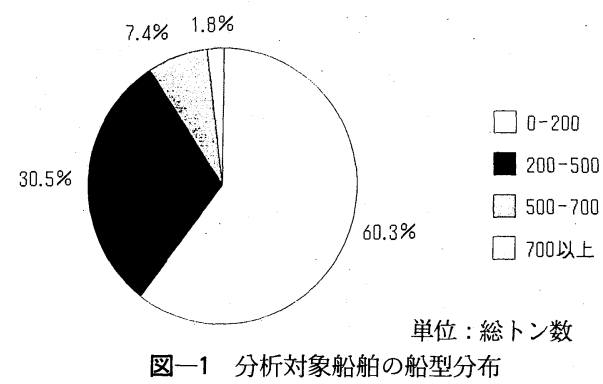

\section{3. 使用データの概要とトリップ連鎖パターンの 類型化}

\section{（1） 使用データの概要}

\section{a) 調查内容}

本研究で使用したデータは, 大阪湾とその周辺海域を 航行する内航船舶を対象に, 昭和 59 年 10 月 1 日から 10 月 31 日の 1 力月間に (社) 神戸海難防止協会 (大阪湾交 通システム調查研究委員会) によって行われた起終点調 査である ${ }^{8)}$. ここで大阪湾とその周辺海域とは, 大阪府, 兵庫県（日本海側を除く）, 和歌山県に面した海域をさ す.また, 起点もしくは終点は, 大阪湾とその周辺海域 内は個々の港ごとに 31 地点, それ以外の海域は各港を その港が所在する都道府県名で代表させ合計 36 地点, 総計 67 地点が設定されている.

主たる調查内容は，a．船舶の属性 (船種・船型), b. 1 力月間の全航海の記録, c. 1 力月間の全積載貨物の種 類と量およびその仕出港 - 仕向港などで, 船舶の流動と それによって輸送される貨物の流動とを同時に把握でき ることを大きな特徴としている.

\section{b) 分析対象船舶}

本研究では上記の調查デー夕より, 内航船舶における 主要船種である一般貨物船を分析対象とした。 なお, 調 查結果の有効船舶隻数 1,263 隻の内，一般貨物船は 557 隻で 44\%を占めていた. 図一1 はこれらの一般貨物船 557 隻の船型分布を調べたあのである.これによれば， 60\%以上が 200 総トン未満の船舶であり’ 700 総トンを 越える船舶は非常に少なくなっているのがわかる。ま た, 内航貨物船の保有隻数に対するサンプリング率（= サンプル隻数／全内航貨物船保有隻数）は $24.3 \%$ (= 557 隻 $/ 2,293$ 隻 (日本商船船腹統計 1984 年版より)), 平均船型では調查結果で 365.7 総トン, 保有船舶全体で 346.2 総トン（日本商船船腹統計 1984 年版より）となっ ており, 本調查では比較的良好なサンプルが得られてい ると考えられる. 


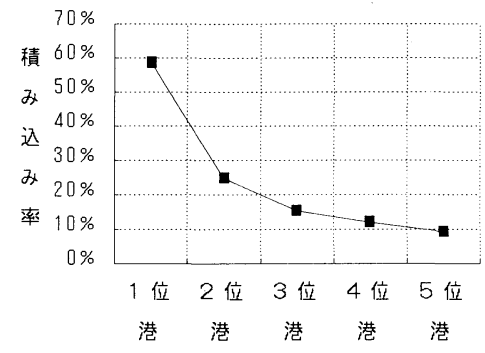

図一2 積み込み貨物量上位 5 港の平均積み込み率

（2）ベース港の決定とトリップ連鎖パターンの類型化 a） ベース港の決定方法

先に述べたように，船舶交通の分析にトリップチェイ ンの考え方を適用するには，まずべース港を決定する必 要がある. 船舶のベース港には, 「常にその船舶が係留さ れる港」や「船舶の登録場所」,「貨物の積み込み量や揚 げ卸し量の多い港」などが考えられる。しかし，通常船 舶が係留されるのは，検船や保守などのためであり，船 舶の登録場所は単なる事務手続上のあのでしかないな ぞ，これらは貨物輸送のための運航とは関係のない港で ある. 本研究では貨物輸送の立場から船舶の運航を分析 しようとしているため，このような港をべースとするこ とは適当であるとは言い難い，貨物輸送の立場から考え ると,「貨物の積み込み量や揚げ卸し量の多い港」をべ一 スとすることが考えられる，そこで，起終点調査の結果 から積み込み港と揚げ卸し港のそれぞれの総数を調べた ところ, 積み込み港の総数は揚げ卸し港の総数より $20 \%$ 程度少なく, 船舶の運航は積み込み港加ら揚け卸し港へ 貨物を分配するような運航形態をしているものと考えら れた，そのため，本研究では各船舶の寄港地のうちで貨 物の積み込み量が最む多い港をその船舶にとってのべー ス港であるあのとする。

図一2 は各船舶の寄港地のうちで積み込み貨物量の多 い上位 5 港について，その船舶の全積み込み貨物量に対 する各港での比率（以下，積み込み率）を図示したもの である。これによれば， 1 位港での積み込み率が $60 \%$ 近 くあり，1位港がその船舶にとって重要な貨物の積み出 し拠点となっているあのと考えられる．また，このよう な積み込み貨物量 1 位の港をべースとしたトリップ連鎖 パ夕ーンを考えると，貨物の揚げ積みがその連鎖パ夕ー ン内でほぼ完結していることや, 積み込み貨物量 1 位の 港は寄港回数む他港に比べて非常に多くなっていること など，ベースとなる条件を非常によく満たしていると言 える.

b） トリップ連鎖パターンの類型化 ${ }^{10)}$

本研究では, 各船舶の一ケ月間の運航を（1）で決定 したベース港を出発し，再びこのべース港に戻ってくる

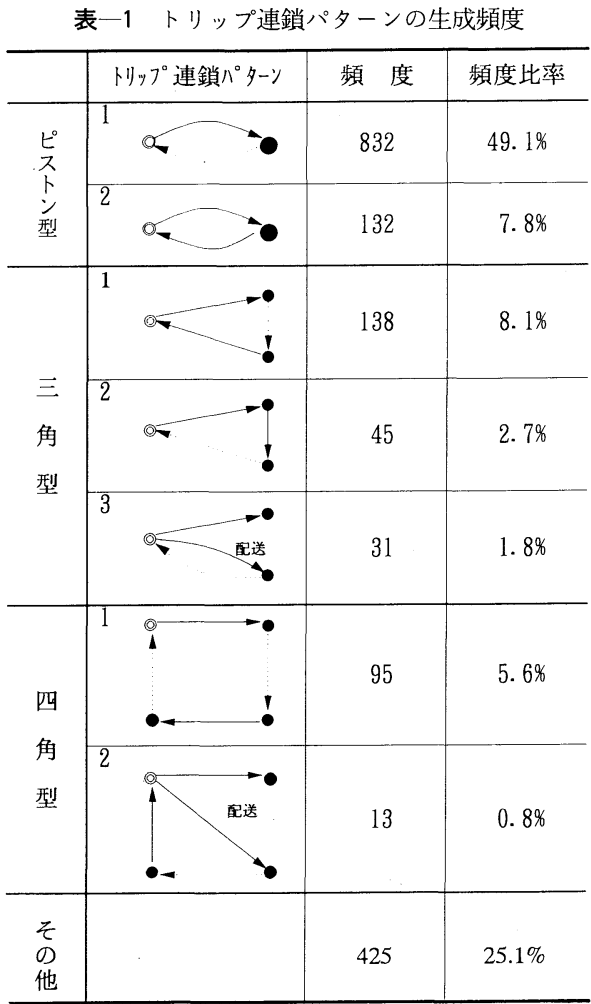

注）○はベース港を，○は訪問港を示す.

$\rightarrow$ は貨物輸送, $\cdots$ は空船回航を意味する.

までのトリップの連鎖に区切り，そうした一連のトリッ プ連鎖をその連鎖内に存在する訪問港の数や貨物の輸送 形態に着目することで，1つのトリップ連鎖パターンと して類型化した. したがって，各船舶の運航はこうした 連鎖パターンの組み合わせで表わすことができる．表一 1 はこのように類型化されたトリップ連鎖パターンの代 表的なむのについてその頻度比率を示したものである.

これによれば，まず頻度比率について見ると，ベース 港で積み込んだ貨物を他の港へ輸送し，そのまま空船で ベース港へ帰港するというピストン型 1 が，全体の約半 分を占めており，このパターンが船舶の運航において最 あ一般的なパターンであると考えられる。 また，ピスト ン型, 三角型, 四角型のこれらのパターンを合計すると 全体の約 $75 \%$ を占めている。なお，「その他」の連鎖パ ターンも $25 \%$ 程度存在しているが，これらのうち大半は 同一港内でのバース間の移動で，貨物輸送を伴わないパ ターンであった。 また，それ以外のものは訪問港の数が 4 港以上のパターンなどであり，これらはいずれも貨物 輸送との関連が明確でなかったり, 個々の比率が小さく ベース港の決定による䛊差から生じたものと考えられ た.

次に貨物の輸送形態について見ると，いずれの連鎖パ 


\begin{tabular}{|c|c|c|c|}
\hline \multirow{2}{*}{ 説明変数 } & \multicolumn{2}{|c|}{ 標準化正準判別係数 } & \multirow{2}{*}{$\mathrm{F}$ 值 } \\
\hline & 判別関数 I & 判別関数 II & \\
\hline $\begin{array}{l}\text { 第 } 1 \\
\text { トリップ長 }\end{array}$ & 0.9118 & 0.2421 & $\begin{array}{l}59.007 \\
* *\end{array}$ \\
\hline $\begin{array}{l}\text { 第 } 1 \text { 忓 } \\
\text { の積載率 }\end{array}$ & 0.1243 & -0.2790 & 2.017 \\
\hline 総トン数 & -0.4633 & 0.2023 & $\begin{array}{l}17.599 \\
* *\end{array}$ \\
\hline ベース港の & -0.4147 & 0.8875 & $\begin{array}{l}13.643 \\
* *\end{array}$ \\
\hline $\begin{array}{l}\text { ベース港の } \\
\text { 移入貨物量 }\end{array}$ & 0.3867 & 0.2088 & $\begin{array}{c}13.161 \\
* *\end{array}$ \\
\hline $\begin{array}{c}\text { 正 準 } \\
\text { 相関係数 }\end{array}$ & 0.52419 & 0.14506 & \\
\hline
\end{tabular}

注 1）外的基準は表-1における三角型 3、四角型 2 を除く 各連鎖パターン

注 2 ）*は有意水準 $5 \%$ て、**有意水準 $1 \%$ で有意である ことを意味する。

注 3 ) いずれの判別関数も有意水準 $1 \%$ で有意。

ターンにおいてあ第 1 トリップ，すなわちベース港を起 点とし最初の訪問港を終点とするトリップは貨物輸送を 行っており，このことからあ，ベース港は各船舶におい て重要な貨物の積み出し拠点となっていることがわか る.

また，三角型 3 や四角型 2 に見られるような貨物の配 送を行っているパターンああるが，その比率む小さく， 配送型の輸送形態は通常の 1 港積み 1 港揚げの輸送形態 とはまったく構造が異なっているものと考えられるた め, 以下の分析対象から除くこととした。なお，三角型 2 については比率は小さいむのの，輸送形態は 1 港積み 1 港揚げを行っており，三角型 1 とは空船トリップの現 れ方が異なるのみであるため，その形成メカニズムも三 角型 1 から推定できるあのと考え分析対象とすることと した。

\section{4. トリップ連鎖パターンの形成要因の分析}

\section{（1）トリップ連鎖パターンの正準判別分析 ${ }^{11)}$}

前節において，内航船舶におけるトリップ連鎖パター ンの主なあのを示したが，本節ではまず，これらのパ ターンがいかなる要因によって決定づけられるかを，表 -1 における三角型 3 , 四角型 2 を除く各連鎖パターン を外的基準とする正準判別分析によって分析した．その 要因としては, 「船舶の属性」,「べース港の規模やベース 港で積まれる貨物の種類」「連鎖パターンの属性」など を考えた。しかしながら、「ベース港で積まれる貨物の種 類」については，図一4 の分析で示すように，第 1トリッ プで輸送される貨物（ベース港で積まれる貨物）の種類 数は $77 \%$ 以上の船舶が 1 種類のみの貨物 (主として鉄鋼 関係の貨物) を輸送しており，こうした傾向は連鎖パ ターンごとで差が無いことなどから考えて，ベース港で



図一3 第 1 トリップ長の距離帯別による各連鎖パターンの構成 比率

積まれる貨物の種類には大きな差が無いむのと考えられ るため, 分析から除くこととした.

したがって，分析に用いた変数は次の 5 っとした，(1) 船舶の属性として船舶の総トン数，(2)べース港の規模と してベース港の移出貨物量, (3)同じくベース港の移入貨 物量 (いずれすフレート・トン), (4)連鎖パターンの属性 として各連鎖パターンの第 1 トリップの長さ（単位はマ イル), (5)同じく第 1 トリップの積載率 (=フレートトン /DWT (載貨重量トン数)).

表一2 は分析結果を示したあのであり，表中では統計 的に有意（有意水準 $5 \%$ ）であった $2 つ の$ 判別関数のみ を示している．これによるとまず，正準相関係数は，判 別関数 I では 0.524 , 判別関数 II では 0.145 といずれも あまり高いとはいえないが，第 1 トリップの積載率を除 く 4 つの変数は有意水準 $1 \%$ で統計的に有意となってい る. また F 值をみると，第 1 トリップ長の F 值が他に比 べ大きくなっており，第 1 トリップ長が連鎖パターンを 形成する上で，大きな要因となっていることがわかる.

\section{（2）第1トリップ長とトリップ連鎖パターンの構成比 率}

次に，連鎖パターンを決定づける主な要因である第 1 トリップ長により，連鎖パターンの構成比率がどのよう になっているかを分析した，図一3は，第1トリップ長 の各距離帯ごとに各連鎖パターンの構成比率（各距離帯 ごとの各連鎖パターンごとのシェア）を示したものであ る.これによれば，ベース港への帰港時に貨物輸送をと あなわないピストン型 1 では，第 1 トリップ長が長くな ると構成比率が小さくなる。これに対し，空船トリップ をともない貨物輸送を行う三角型 1 と 2 ，抒よび四角型 1 では, 300 から 400 マイルの距離帯やそれ以上の距離 帯にピークがみられ，第 1 トリップ長が長いほど訪問港 数の多い連鎖パターンの構成比率が大きくなる傾向を示 している，ただし，全く空船トリップを生じないピスト ン型 2 では，第 1 トリップ長による構成比率の差異には 
a) 第 1 トリップ

$4.8 \%$

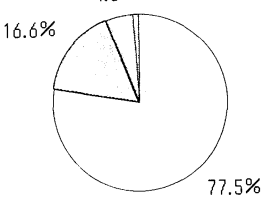

$16.2 \%$

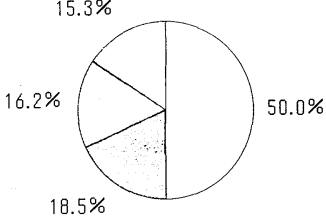

図一4 積載貨物の種類数の分布

明確な傾向は見られなかった。

\section{（3）第 1 トリップにおける貨物の輸送特性}

第 1 トリップはいずれの連鎖パターンにおいても必ず 貨物輸送をともなっている，そこでここでは，第 1 卜 リップと第 1 トリップ以外の貨物輸送をともなうトリッ プとの間で, 積載されている貨物の種類数や積載率を比 較することにより，連鎖パターン内における第 1 トリッ プの役割を考察する。なお，ここで分析対象としたのは 第 1 トリップ以外でも貨物輸送を行っているピストン型 2, 三角型 1 と , 四角型 1 の 4 パターンである.

まず図一4は，同一連鎖パターン内における第 1 卜 リップおよびそれ以外の貨物輸送をともなうトリップに ついて, 各船舶が輸送している貨物の種類数の分布を図 示したものである.なおここでは，こうした分析を各連 鎖パターンごとに行ったがパターンごとの結果に大きな 差がなかったため, 全パターンを集計したもののみを掲 載した.これによれば, 第 1 トリップでは, 1 種類のみの 貨物を輸送している船舶が全体の $77.5 \%$ あるのに比 べ，その他のトリップでは $50.0 \%$ と低くなっている，こ れは, 第 1 トリップでは, ベース港というその船舶に とって重要な貨物の積み出し拠点となっている港で積み 込まれる貨物を輸送しているため, 貨物の種類が限られ ているあのと考えられる.

また表一3 は，第 1 トリップの積載率と第 1 トリップ 以外で貨物輸送をともなうトリップの積載率を, 平均值 の検定を用いて比較, 分析した結果である.これによれ ば，いずれの連鎖パターンの検定結果す第 1 トリップの 積載率がその他の貨物輸送をともなうトリップの積載率 よりも高くなっていることがわかる.

このように第 1 トリップでは，限られた種類の貨物を 輸送していること，他の貨物輸送をともなうトリップに 比べて積載率が高くなっていることなど，各船舶にとっ て主要な貨物を輸送しているものと考えられる。すすお ち, 各船舶はべース港で積み込まれる貨物を輸送するこ とを中心として配船・運航されており，第 1 トリップ以 外で行われる貨物輸送は，そうした貨物を積み込むため にベース港に戻って、る際の，いわゆる帰り荷輸送であ るあのと考えられる.
表一3 第 1 トリップとその他の貨物輸送をともなうト リップの積載率の比較

\begin{tabular}{c|c|c|c}
\hline \multirow{2}{*}{$\begin{array}{c}\text { 連 鎖 } \\
\text { パターン }\end{array}$} & \multicolumn{2}{|c|}{ 平均積載率 } & \multirow{2}{*}{$\mathrm{t}$ 值 } \\
\cline { 2 - 3 } & 第1トリップ & その他のトップ & \\
\hline $\begin{array}{c}\text { ピストン } \\
\text { 型 }\end{array}$ & $\begin{array}{c}0.924 \\
(0.6770)\end{array}$ & $\begin{array}{c}0.554 \\
(0.3114)\end{array}$ & $\begin{array}{c}6.6740 \\
* *\end{array}$ \\
\hline 三角型 1 & $\begin{array}{c}0.873 \\
(0.2867)\end{array}$ & $\begin{array}{c}0.801 \\
(0.2693)\end{array}$ & $\begin{array}{c}2.8694 \\
* *\end{array}$ \\
\hline 三角型 2 & $\begin{array}{c}0.934 \\
(0.5568)\end{array}$ & $\begin{array}{c}0.848 \\
(0.7157)\end{array}$ & $\begin{array}{c}* .7083 \\
* *\end{array}$ \\
\hline 四角型 1 & $\begin{array}{c}0.860 \\
(0.2827)\end{array}$ & $\begin{array}{c}0.759 \\
(0.3170)\end{array}$ & $\begin{array}{c}3.4861 \\
* *\end{array}$ \\
\hline
\end{tabular}

注 1)その他のトリップとは、第 1トリップ以外の貨物 輸送をともなうトリップを意味し、各パターンにおける 位置は表一 1 を参照のこと。

注 2 ）平均積載率の下の（）内の数字は標準偏差を意味 する。

注 3 ） $\mathrm{t}$ 值の下の**は有意水準 $1 \%$ で有意であること を示す。

\section{5． 帰り荷貨物の選択要因の分析}

\section{（1）判別分析による帰り荷貨物の OD 選択要因の分析}

ここでは, 各船舶が多くの OD 貨物の中からどのよう な要因を基準にして帰り荷貨物を選択しているかを明ら かにする，なお，分析対象は帰り荷があり，第 1 トリッ プ長による構成比率に明確な傾向がみられる三角型 1 , 三角型 2 ，および四角型 1 に限った。

そこで，分析対象とした各連鎖パターンについて，各 OD 貨物が畄り荷貨物として選択されるかどうかを，以 下の判別関数により分析を試みた.

$z=a \cdot \ln _{e}(\mathrm{OD}$ 貨物量 $)$

$+b \cdot \ln _{e}$ (帰り荷貨物の輸送距離 / 第 1 トリップ長）

$+c \cdot \ln _{e}$ (空船回航長 / 第 1 トリップ長 $)$

$+d$

\section{ここで，空船回航長とは}

三角型 1 では第 2 トリップのトリップ長 三角型 2 では第 3 トリップのトリップ長

四角型 1 では第 2 トリップと第 3 トリップの 合計長を意味する.

ここで $る$ は，判別分析の外的基準となるもので，その OD の貨物が帰り荷として選択されるか否かを示してい る.なお，各連鎖パターンの㷌り荷貨物の選択されやす さは，OD貨物量とその OD 距離に比例し，また，その OD 貨物を選択した際に行われる空船回航長に反比例す るものと考え，これを線形化したもの，すなわち，OD 貨 物量, 㷌り荷貨物の輸送距離, および空船回航長それぞ れを対数変換したものを説明変数として分析を行った. ただし, OD 貨物量以外の 2 変数はいずれも第 1 トリッ プ長で基準化しているが，これは以下の理由による，図 
表一4 判別分析による帰り荷貨物の選択要因の分析

\begin{tabular}{|c|c|c|}
\hline 変数名 & 判別係数 & $\mathrm{F}$ 值 \\
\hline 空船回航率 & -9.5502 & $638.299^{* *}$ \\
\hline $\begin{array}{l}\text { 貨物 } 9 \\
\text { 輸送距離率 }\end{array}$ & 0.8514 & $4.092 *$ \\
\hline OD貨物量 & 0.4062 & $59.257 * *$ \\
\hline 定 数 & 3.1800 & - \\
\hline 各群の重心 & $\begin{array}{r}4.2111 \\
-0.0279 \\
\end{array}$ & $\begin{array}{c}\text { 選択されたOD } \\
\text { 選択されなかった } \\
\text { OD } \\
\end{array}$ \\
\hline 正判別率(\%) & 84.298 & \\
\hline \multicolumn{3}{|c|}{ 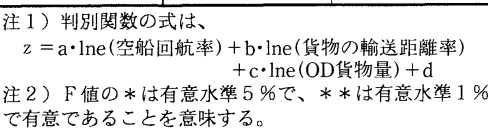 } \\
\hline
\end{tabular}

一3で示したように第 1 トリップ長によって各連鎖パ ターンの構成比率が異なっていること, またさらに, 帰 り荷貨物の輸送距離および空船回航長について, 第 1 卜 リップ長との相関係数を調べたところ，前者は 0.774 , 後者は 0.275 (いずれも有意水準 $5 \%$ で有意）となってお り，第 1 トリップ長が長くなれば，これらあそれに応じ て長くなる傾向があると考えられるためである.

なお，以下では空船回航長を第 1 トリップ長で基準化 したものを空船回航率, 帰り荷貨物の輸送距離を第 1 卜 リップ長で基準化したものを貨物の輸送距離率と呼ぶこ ととする.

分析に際しては, 第 1 トリップとなる 1 組の OD ごと に，帰り荷貨物の選択候補となるすべての OD 貨物量 （第 1 トリップと貨物量がない OD を除く貨物量の OD 表), および, それらに対応した貨物の輸送距離率と空船 回航率が必要となり，デー夕量が非常に多くなる，そこ で，以下の OD ペアについては選択候補となる OD 貨物 から取り除いた。 (1)空船回航率が 1 を越えるものが全体 の $20 \%$ 程度と少なかったことから, 空船回航率が 1.5 を 越える OD ペア ${ }^{12)}$. (2)空船回航長と帰り荷貨物の輸送距 離の合計が第 1 トリップ長の 2.2 倍を越える連鎖パター ンには, 積載率が第 1 トリップよりあ高いあのが多く, これは, 今回用いたベース港の決定方法による誤差と考 えられることから, 空船回航長と帰り荷貨物の輸送距離 の合計が第 1 トリップ長の 2.2 倍を越える OD ペア.

この結果, データからの各連鎖パターンのサンプリン グ率は三角型 1 で $82.6 \%$ (114 サンプル), 三角型 2 で $64.4 \%$ (29 サンプル), 四角型 1 で $67.4 \%$ (64 サンプル) となった。

表一4 はこのような判別分析の結果を示したものであ る.これによれば，正判別率は $84.3 \%$ （誤判別率は 15.7\%）となっており良好な值を示している．また，表 一 5 に示した連鎖パターンごとの正判別率（全体での判
表一5 各連鎖パターンの正判別率

\begin{tabular}{l|c|c}
\hline $\begin{array}{c}\text { 連 鎖 } \\
\text { パターン }\end{array}$ & $\begin{array}{c}\text { 全体での } \\
\text { 正判別率(\%) }\end{array}$ & $\begin{array}{c}\text { 選択された } \\
\text { のの正判別率 }\end{array}$ \\
\hline 三角型 1 & 53.7 & 87.8 \\
\hline 三角型 2 & 44.8 & 94.7 \\
\hline 四角型 1 & 88.9 & 74.2 \\
\hline 注)いずれの正判別率も、表-4の判別分析によっ \\
て正しく判別さ机た比率
\end{tabular}

別率）をみると, 四角型 1 の判別率が $88.9 \%$ と高い值を 示しているものの, 三角型 1,2 の判別率は決して高いと は言えない. しかしながら, 帰り荷貨物として選択され た OD ペアのみの判別率を見ると最も判別率の低い四角 型 1 でも $74.2 \%$ となっており, 䚻り荷貨物の選択要因を 知るには良好な結果と考えられる.

次に各変数についてみると, いずれの変数屯有意水準 $1 \%$ よび $5 \%$ で有意となっており, 帰り荷貨物の輸送距 離が長く, 貨物量が多く, 空船回航率が小さくなるよう なOD 貨物ほど，すなわち言い換えれば，輸送効率が高 くなるような，経済的にみて有利な OD 貨物ほど帰り荷 輸送の貨物として選択される可能性が大きいことがわか る. さらに F 值についてみると, 空船回航率の F 值が他 に比べ非常に大きくなっており, 㷌り荷貨物を選択する 際に, 空船回航率が小さいことが最も重要な条件となっ ていることがわかる.

\section{（2）空船トリップ長の分析}

先の（1）では, 空船回航率が小さくなるように帰り 荷貨物が選択されていることを述べた。ここでは，こう した要因が図一3の分析で示したような第 1 トリップ長 による連鎖パターンの構成比率の差異によ゙のように反映 しているかを検討する.

図一5 は, 三角型 1 と 2 の各空船トリップ長，および 四角型 1 の 2 つ空船トリップ長それぞれについて，そ の分布状況を図示したものである.これによれば，三角 型 1 と 2 の空船トリップ長の分布あ四角型 1 の 2 つの空 船トリップ長の分布も, 短い距離帯ほどその比率が高く なる傾向を示していることなど，似通った分布状況が見 られる.

そこで，まず表一6に三角型 1 と 2 の空船トリップ, および四角型 1 の 2 つの空船トリップそれぞれの平均長 を示した. そしてさらに，それらの間に統計的に有意な 差があるかどうかを，表一7で示すような第 1 トリップ 長を共変量とした共分散分析によって調べた。ここで, 第 1 トリップ長を共変量としたのは次のような理由によ る.すなわち，（1）と同様に各連鎖パターンの構成比率 が第 1 トリップ長によって異なること, さらに, 空船回 航長が第1トリップと小さいながらも統計的に有意な正 の相関を有しており，各空船トリップ長む第 1 トリップ 長と相関があると考えられることなど, 空船卜リップ長 


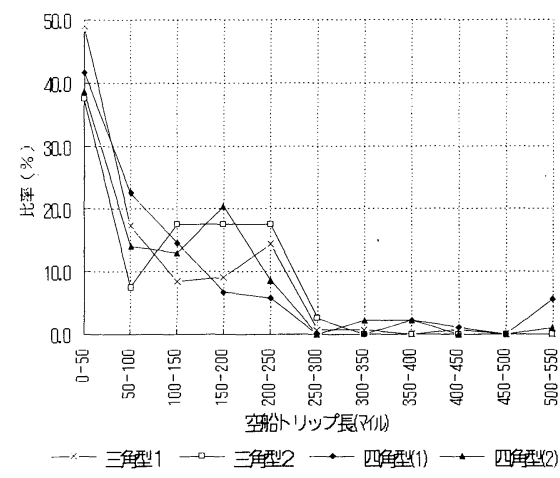

図一5 空船トリップ長の分布
表一6 平均空船トリップ長

\begin{tabular}{|c|c|}
\hline $\begin{array}{l}\text { 連 鎖 } \\
\text { パターシ }\end{array}$ & $\begin{array}{l}\text { 平均空船 } \\
\text { トリップ長 }\end{array}$ \\
\hline $\begin{array}{l}\text { 三角型 } 1 \\
\text { 第 } 2 \text { トリッ }\end{array}$ & $\begin{array}{c}92.6 \\
(87.4)\end{array}$ \\
\hline $\begin{array}{l}\text { 严角型 } 2 \\
\text { 第 }\end{array}$ & $\begin{array}{l}111.5 \\
(81.5)\end{array}$ \\
\hline $\begin{array}{l}\text { 四角型 } 1 \\
\text { 第 } 2 \text { リッフ }\end{array}$ & $\begin{array}{c}111.5 \\
(133.6)\end{array}$ \\
\hline $\begin{array}{l}\text { 四角型 } 1 \\
\text { 第 } 4 \text { 訬, }\end{array}$ & $\begin{array}{c}108.7 \\
(102.5)\end{array}$ \\
\hline
\end{tabular}

注）平均空船トリップ長の単位 はマイル、その下の 0 内の数字 は、標準偏差を意味する。
表一7 空船トリップ長の共分散分析

\begin{tabular}{|c|c|c|}
\hline 因 & 平均平方和 & 值 \\
\hline $\begin{array}{c}\text { 第 } 1 \text { ト川ๆ } \\
\text { (共変量) }\end{array}$ & 165122. 991 & $\begin{array}{l}15.808 * * \\
(0.000)\end{array}$ \\
\hline $\begin{array}{l}\text { トップ連鎖 } \\
\text { パターシ }\end{array}$ & 1089.454 & $\begin{array}{c}0.104 \\
(0.958)\end{array}$ \\
\hline 残 & 10445.465 & \\
\hline 全 体 & 10808.243 & \\
\hline
\end{tabular}

注 1 ）トリップ連鑽パターンのカテゴリーは

1. 三角型 1 第 2 トリップ 2. 三角型 2 第 3 トリップ 3. 四角型 1 第 2 トリップ 4. 四角型 1 第 4 トリップ 注 2 ) $\mathrm{F}$ 值の横の**有意水準 $1 \%$ で有意であるこ とを意味する。

注 3）F 値の下の（）内の数字は有意確率を意味す る。
を連鎖パターン間で比較するには，第 1 トリップ長の影 響を除く必要があると考えられるためである，また，図 一 5 に示すようにいずれのパターンの空船トリップ長む 正規分布をしているとは考えにくいが，共分散分析等に 使用される F 検定には比正規性に対する頑健性 (robustness）を有しており，分析の信頼性には影響が少ないむ のと考元られる ${ }^{13)}$.

これらによれば，まず共分散分析の結果より，共変量 である第 1 トリップ長の影響は統計的に有意之なってお り，各空船トリップ長は第1トリップ長によって異なる 長さとなっていることがわかる，一方，連鎖パターン間 の空船トリップ長においては統計的に有意な差が見られ ず，いずれの平均空船トリップ長も 100 マイル前後で， 三角型 1 と 2 の空船トリップ長および四角型 1 の 2 つの 空船トリップ長には大きな差がないことがわかる.

すなわち，これらを連鎖パターン内の空船トリップ長 の合計である空船回航長で考えると, 四角型 1 は, 三角 型の空船トリップ長とほぼ等しい空船トリップが $2 つ$ つ るため, 三角型の 2 つのパターンに比べ長い空船回航長 は必然的に長くなる。

こうしたことから，図一-3の分析結果に示すように第 1 トリップ長が短い時には四角型 1 よりも三角型の比率 が高くなる理由を考察すると次のようになる。すなわ ち, 四角型 1 では三角型に比べ空船回航長が長くなる. そこで, 5-1 の分析結果のように空船回航率が小さくな るように帰り荷貨物を選択しようとすれば，四角型 1 を 行う時は三角型を行う時に比べ第 1 トリップ長が長く なっていることが必要となるため，第 1 トリップ長が短 い之きは三角型の比率が大きくなるものと考えられる.

\section{6. 連鎖パターンの形成メカニズムの考察}

以上得られた分析結果より連鎖パターンの形成メカニ ズムについて考察すると次のようになる。

まず各船舶は，その船舶における貨物の重要な積み出
し拠点之考えられるべース港を中心に配船・運航されて いるものと考えられる．すなわち，各船舶は第 1 トリッ プで行う貨物輸送を中心に運航されており，この第 1 卜 リップが終了し再びベース港へ戻る際の船舶の動向によ り，各連鎖パターンが形成されている，そして，このよ うに第 1 トリップが各船舶の主要貨物を輸送しているこ とは以下の 3 点より示した。すすなわち，ベース港が各船 舶の重要な貨物の積み出し拠点となっていること, 第 1 トリップで輸送される貨物の種類がその他のトリップで 輸送される貨物の種類よりあ安定していること,さらに 第 1 トリップの積載率が他の貨物輸送をともなうトリッ プの積載率よりも高いことであった。

次に，こうした第 1 トリップが終了しべース港に帰港 する際，その訪問港でベース港へ輸送する帰り荷貨物が あればピストン型 2 の連鎖パターンとなるが，通常こう したことは少なく，ベース港への復路が空船トリップと なるピストン型 1 になる，またこの場合，第1トリップ 長が長いと復路の空船も長くなり, 運航効率が悪くなる ので空船回航を行って帰り荷を探すことになる。これ は, 図一3 の分析で第 1 トリップ長が長くなるとピスト ン型 1 の比率が小さくなることからあ考察される.

また, 空船回航を行い帰り荷輸送を行う場合, 空船卜 リップを 1 回行えば三角型 1 または三角型 2 となり， 2 回行えば四角型 1 となる。ここで, 帰り荷貨物を選択す る際には，5.（1）の分析で示したように空船回航率を できるだけ小さくすることが重要な条件となっている. そのため，5.（2）の空船トリップ長の分析で示したよ うに, 四角型 1 では, 空船トリップが 1 回の三角型より 屯空船回航長が長くなるため, 第 1 トリップ長が三角型 よりあ長い時に行われることが多くなる。こうした結 果, 図一 3 に見られるように, 三角型 1 では 300 から 400 マイルの距離帯で生成率がピークとなり, それ以上の距 離帯では比率が小さくなっていくのに対して, 四角型 1 では第 1 トリップ長が長いほど構成比率が大きくなる傾 向が見られるものと考えられる. 


\section{7. おわりに}

本研究では, 内航船舶を対象に行われた起終点調査の 結果をもとに, 内航船舶の主要船種である一般貨物船に おけるトリップ連鎖パターンの形成メカニズムを明らか にすることを目的としたものである，この結果，以下の 成果を得ることができた。

(1)ベース港を出発し再びベース港に戻ってくるまでの一 連のトリップ連鎖を，その訪問港数や貨物の輸送形態に 着目することで類型化した. その結果, ピストン型 1,2 , 三角型 $1 ， 2$, 四角型 1 など，主だった 5 つの連鎖パター ンを抽出できた。ささらにこれらの連鎖パターンの構成 比率が第 1 トリップの長さにより異なることを示した. (2)連鎖パターンの形成メカニズムは次のように考察され た.すなわち，各船舶はベース港を起点としている第 1 トリップを中心に運航されており，抽出されたそれぞれ の連鎖パターンは，このような第 1 トリップが終了し再 びベース港へ帰港する際に生じる空船回航を避けるた め, 空船回航率をできるだけ小さくするように帰り荷貨 物を選択することで形成されていた。

(3)また，こうした帰り荷輸送を行うか否かということ や，帰り輸送にともなう空船回航長などは，第 1 トリッ プ長に大きく依存しており, 第 1 トリップ長によって連 鎖パターンの構成比率が異なる理由む，連鎖パターンの 形成メカニズムにより説明できることを示した。

このように，一般貨物船のトリップ連鎖パターンの形 成メカニズムはほぼ明らかにできたと考える，今後の課 題としては以下の点あげられる.

(1)本研究は起終点調査の結果をもとに連鎖パターンの形 成メカニズムを考察したあのであり，言うなれば配船結 果をもとにその運航形態やそれに潜む意志決定構造を考 察しようとしたものである，そのため，配船担当者の意 識調查などにより本研究で得られた結果の妥当性につい て検討する必要がある.

(2)本研究で得られた連鎖パターンの形成メカニズムにも
とづき配船モデルを構築することによって，与えられた 貨物流動量から船舶交通量を推計する手法を構築してい く必要がある.

最後に，内航船舶を対象とした起終点調査は，筆者ら が参加した大阪湾交通システム調查研究委員会のもとで （社）神戸海難防止研究会によって実施されたあのであ る.

\section{参考文献}

1）近藤，菊池：トリップパタンに関する二，三の考察，交通 工学, Vol. 21, No. 2, pp. 7-14, 1986 年.

2）佐々木，西井：トリップチェイン手法を用いた都市内業務 交通の発生集中量の分析, 土木学会論文報告集, 第 327 号, pp. 129-138，1982 年.

3）たとえば,

西井和夫：時空間制約下に扔ける 2 ストップチェインのパ ス選択モデル, 土木学会論文集, No. 470/IV-20, pp. 105114,1993 年.

加藤，門田，高瀬：時間制約下における通勤者の私的交通 分析, 土木学会論文集, No. 449/IV-17, pp. 97-106, 1992 年.

4）加藤，門田：時間帯別業務交通の推計手法の関する実証研 究，土木学会論文集，No. 431/IV-15，pp. 115-124，1991 年.

5）岡山，小谷：内航一般貨物船のトリップ連鎖パターンに関 する分析, 土木計画学研究・講演集 15, pp. 655-662, 1992 年.

6）岡山，小谷：内航船舶の運航と貨物の輸送特性の分析，日 本沿岸域会議論文集 4, pp. 91-102，1992 年.

7）西井和夫：都市内貨物車の運行パターンに関する基礎的考 察, KIIS (財) 関西情報センター, Vol. 42 , pp. 1-8, 1982 年.

8）神戸海難防止研究会：内航船舶による貨物輸送の実態解析 報告書, 1984 年

9）前掲 6)

10）岡山，小谷：内航一般貨物船におけるトリップ連鎖パ夕一 ンの形成過程に関する一考察，土木学会第 48 回年次学術 講演会講演概要集第 4 部, pp. 782-783，1993 年.

11） 岡山，小谷：内航一般貨物船によるトリップ連鎖パターン の特性に関する分析，広島商船高等専門学校紀要，第 15 号, pp. 167-175，1993 年.

12）前掲 10)

13）たとえば, 田中 豊：パソコン実験計画法入門，現代数学社,pp. 207 $-216,1985$ 年.

石村貞夫：分散分析のはなし，東京図書，p. 19，1992 年.

(1994.1.31 受付)

\title{
ANALYSIS ON MECHANISM FOR FORMING TRIP PATTERNS OF COASTAL CARGO SHIPS
}

\author{
Michiyasu ODANI and Masato OKAYAMA
}

\footnotetext{
The purpose of this paper is to analyze a mechanism for forming trip pattems of coastal cargo ships, based on the Origin-Destination survey given to their operators. First, ships' trip chains made by the ships which start from and return to their base port through several trips are classified into several trip patterns by the number of sojourns and the cargo transport activities in their chains. Second, it is shown that the length of the first trip in a trip pattern is an important factor to form each pattern, and that one of the other trips with a cargo transportation is a return cargo transportation. Finally, it is made clear that load factor is one of the most significant factors to choose a return cargo OD.
} 